\title{
PENGUKURAN LAJU PAPARAN RADIASI PADA RUANG PEMERIKSAAN MSCT 64 SLICE
}

\author{
Elisa Fitriani ${ }^{1)}$, Gatot Murti Wibowo ${ }^{2)}$ \\ ${ }^{1}$ RSI Rembang, ${ }^{2}$ Poltekkes Kemenkes Semarang \\ e-mail: elisafitriani59@gmail.com
}

\begin{abstract}
Background:Radiation exposure rate measurements have been done on the MSCT 64 Slices examination room radiology section Dr. Moewardi Surakarta Hospital due to lack of repeat measurement after replacement of examination door. This study aims to determine the rate of radiation exposure and radiation safety in the examination room for workers and public refers to the NCRP report no. 147 about stuctural shielding design for medical x-ray imaging facilities.

Methods: This type of research is quantitative research with survey approach. This research was conducted in March 2018. Data collection was done by observation, documentation, and measure the radiation exposure in measurement points some places, which are controlled and uncontrolled areas. Data analysis was done descriptively by comparing data with NCRP report no. 147.

Results:The measurement results of the rate of radiation exposure, point $\mathrm{A}$ and $\mathrm{B}$ shows the leakage of radiation exposure. While the point of C, D, E no leakage of radiation.

Conclusions: The value of background radiation exposure in the MSCT 64 Slices examination room radiology section Dr. Moewardi Surakarta Hospital exceeds the dose rate base on the height of the location according to UNSCEAR. Leakage of radiation exposure occuring at point A is woorkes door and point B front door MSCT 64 Slices examination room not safe for workes and public because it exceeds the limit of radiation exposure rate value which allowed.
\end{abstract}

Keyword: Radiation Exposure Rate, Measurement

\section{PENDAhuluan}

Pemeriksaan radiodiagnostik dengan memanfaatkan sinar-X dapat mengakibatkan efek samping bagi tubuh manusia terutama bagi pasien yang menjalani pemeriksaan yang secara langsung terkena radiasi, bagi petugas yang berinteraksi dengan sinar- $X$ serta bagi masyarakat umum. Efek samping ini terjadi akibat radiasi yang diserap oleh tubuh dapat mengakibatkan sel-sel dalam tubuh rusak, selsel yang rusak akan dapat menyebabkan gangguan fungsi sel bahkan kematian sel tersebut sehingga mengganggu kesehatan tubuh hingga terjadi kematian sel bagi seseorang. Dengan mengetahui bahaya sinar-X dan bekerja dengan efektif untuk mengurangi bahaya tersebut, manusia dapat meminimalisir kemungkinan terjadinya efek biologi terhadap jaringan. Maka dari itu dibuat tindakan proteksi radiasi (Sherer et al. 2006).

Mengacu pada Peraturan Pemerintah Republik Indonesia Nomor 33 Tahun 2007 tentang Keselamatan Radiasi Pengion dan Keamanan Sumber Radioaktif yang mengatur keselamatan radiasi terhadap pekerja, masyarakat, dan lingkungan hidup, keamanan sumber radioaktif, dan inspeksi dalam pemanfaatan tenaga nuklir. Pemegang izin untuk memastikan Nilai Batas Dosis pekerja dan masyarakat tidak terlampaui, wajib melakukan pemantauan paparan radiasi di daerah kerja secara terus menerus, berkala dan/atau sewaktu-waktu sesuai dengan jenis sumber yang digunakan.

Menurut Perka Bapeten Nomor 8 Tahun 2011 tentang Keselamatan Radiasi dalam Penggunaan Pesawat Sinar-X Radiologi Diagnostik dan Intervensional yang mengatur tentang persyaratan izin, persyaratan keselamatan radiasi, rekaman dan laporan dalam penggunaan pesawat sinar- $\mathrm{X}$, dimana dalam persyaratan keselamatan radiasi salah satunya meliputi verifikasi keselamatan berupa pemantauan paparan radiasi sangat penting untuk dilakukan.

Pembangunan instalasi yang dilengkapi dengan sarana peralatan keselamatan kerja dan sarana pendukung lainnya yang sempurna merupakan hal penting yang perlu mendapatkan perhatian untuk mencegah terjadinya kecelakaan radiasi yaitu sesuai dengan perencanaan yang telah ditetapkan sebelumnya. Beberapa hal yang diperhatikan dalam pembangunan instalasi ruangan pesawat sinar-x sebelum bangunan didirikan antara lain : lokasi bangunan, letak ruangan, desain ruangan, tebal dinding maupun perisai pintu dan kaca (Alkhadi, 2000). 
Dalam perka Bapeten No. 8 tahun 2001 disebutkan bahwa dinding ruangan untuk semua jenis pesawat sinar- $\mathrm{x}$ termasuk pesawat sinar-x CT Scan terbuat dari bata merah dengan ketebalan $25 \mathrm{~cm}$ (dua puluh lima sentimeter) atau beton dengan kerapatan jenis 2,2 gr/cm3 (dua koma dua per sentimeter kubik) dengan ketebalan $20 \mathrm{~cm}$ (duapuluh sentimeter) atau setara dengan $2 \mathrm{~mm}$ (dua milimeter) timah hitam (pb), dan pintu ruangan pesawat sinar-X harus dilapisi dengan timah hitam dengan ketebalan tertentu.

Instalasi Radiologi RSUD Dr. Moewardi Surakarta memiliki dua ruangan pemeriksaan MSCT, yaitu ruang pemeriksaan MSCT 64 Slice dan ruang pemeriksaan MSCT 16 slice yang keduanya di desain terpisah. Ruang pemeriksaan MSCT 64 Slice berada di antara ruang pendaftaran dan ruang pemeriksaan MRI, dengan ruang transit dan kamar mandi pasien berada di depan ruang pemeriksaan, ruang operator MSCT berada disebelah kanan ruang pemeriksaan dengan di batasi dinding penyekat dan terdapat pintu yang menghubungkan ruang pemeriksaan dengan ruang operator. Telah dilakukan pergantian fasilitas perisai radiasi yaitu berupa penggantian pintu menuju ruang operator pada ruang MSCT 64 slice dengan menggunakan galvalum, namun saat penulis mengobservasi pada pintu ruangan tersebut ternyata belum dilapisi dengan $\mathrm{Pb}$.

Setelah dilakukan uji paparan radiasi oleh Bapeten pada tahun 2016, ditemukan adanya kebocoran pada pintu ruang petugas (operator), dan dilakukan tindak lanjut dengan menambah Perisai $\mathrm{Pb}$ sebagai penahan radiasi yang mengarah ke pintu operator. Setelah penambahan Perisai $\mathrm{Pb}$ tersebut dilakukan pengukuran paparan radiasi oleh petugas proteksi radiasi internal, namun tidak dilakukan pemantauan paparan radiasi secara menyeluruh. Selain itu, juga tidak diketahui nilai laju paparan pada ruang MSCT 64 Slice yang akan dijadikan sebagai base line data setelah pengukuran dilakukan.

Berkenaan dengan hal yang dimaksud, penulis ingin mengkaji lebih dalam mengenai pengukuran laju paparan radiasi karena pengukuran laju paparan radiasi ini penting sebagai persyaratan keselamatan radiasi sesuai dengan peraturan yang berlaku sehingga penulis mengambil judul "Pengukuran Laju Paparan Radiasi Pada Ruang Pemeriksaan Msct 64 Slices Di Instalasi Radiologi Rsud Dr. Moewardi Surakarta"

\section{Metode}

Penelitian ini adalah penelitian kuantitatif deskriptif dengan pendekatan survey yaitu dengan menentukan beberapa titik pengukuran yang terbagi pada daerah terkontrol dan daerah tidak terkontrol. Penentuan titik berdasarkan seberapa sering daerah tersebut dihuni oleh pekerja radiasi atau masyarakat luas.

Metode pengambilan data dilakukan dengan tiga tahap yaitu Observasi, Pengukuran dan Dokumentasi. Observasi, yaitu peneliti mengamati secara langsung ruang pemeriksaan MSCT 64 Slice yang meliputi : ukuran dinding, ukuran ruangan, perisai radiasi berupa tabir, pintu, dan ruangan disekitar ruang pemeriksaan MSCT 64 Slice. Pengukuran, Peneliti melakukan pengukuran laju paparan radiasi dengan menggunakan surveymeter Babyline di ruang pemeriksaan MSCT 64 Slice di Instalasi Radiologi RSUD dr. Moewardi Surakarta pada titik yang telah ditentukan yaitu titik di depan pintu pemeriksaan, titik di balik pintu ruang operator, titik di ruang operator, titik diruang tunggu atau ruang pemulihan, dan titik di kamar mandi pasien. Sedangkan Dokumentasi, Peneliti mengumpulkan data-data pendukung yang berhubungan dengan ruang pemeriksaan MSCT 64 Slice, cara pengujian dan hasil laju paparan radiasi di Instalasi Radiologi RSUD dr. Moewardi Surakarta

Pengolahan data dimulai setelah peneliti melakukan pengukuran di sejumlah titik pada daerah terkontrol dan tidak terkontrol yang telah ditentukan dengan menggunakan surveymeter, dengan menggunakan skala $10 \mu \mathrm{Gy} / \mathrm{jam}$ dan faktor kalibrasi 1,05. Pengukuran dilakukan tiga kali disetiap titiknya dengan arah sinar horizontal dan dilakukan perhitungan nilai ukur sebenarnya, kemudian di ambil rata-rata dari setiap pengukuran pada titik-titiknya, didapatkan hasil laju paparan radiasi. Setelah didapatkan hasil pengukuran laju paparan kemudian dikurangi paparan latar untuk mendapatkan laju paparan radiasi sesungguhnya.

Kemudian nilai tersebut dibagi dengan faktor okupansi untuk diperoleh nilai paparan sesuai daerah terkontrol dan tidak terkontrol. Sehingga dapat ditarik kesimpulan dari hasil pengukuran ada atau tidaknya kebocoran radiasi pada ruang pemeriksaan tersebut dan apabila terjadi kebocoran masih dalam batas aman atau tidak.

\section{Hasil dan Pembahasan}

Penelitian ini dilaksanakan secara langsung oleh penulis di daerah terkontrol dan daerah tidak terkontrol pada ruang pemeriksaan MSCT 64 Slice di Instalasi Radiologi RSUD Dr. Moewardi Surakarta dengan melakukan pengukuran laju paparan radiasi sehingga didapatkan hasil pada tabel berikut :

Tabel 4.1 Hasil Pengukuran Laju Paparan Radiasi Sesungguhnya dan Laju Dosis Berdasarkan Ketinggian Suatu Tempat

\begin{tabular}{cccc}
\hline $\begin{array}{c}\text { Titik } \\
\text { Pengukuran }\end{array}$ & $\begin{array}{c}\text { Hasil pengukuran } \\
\text { sesungguhnya } \\
(\mu \mathrm{Gy} / \mathrm{jam})\end{array}$ & $\begin{array}{c}\text { Paparan yang } \\
\text { direkomen- } \\
\text { dasikan } \\
(\mu \mathrm{Sv} / \mathrm{jam})\end{array}$ & $\begin{array}{c}\text { Selisih } \\
\text { pengukuran } \\
(\mu \mathrm{Gz} / \mathrm{jam})\end{array}$ \\
\hline $\mathrm{A}_{\mathrm{DT}}$ & 4,86 & 0,03 & 4,83 \\
$\mathrm{C}_{\mathrm{DT}}$ & 0,02 & 0,03 & 0 \\
$\mathrm{~B}_{\text {DTT }}$ & 3,16 & 0,03 & 3,13 \\
$\mathrm{D}_{\text {DTT }}$ & 0 & 0,03 & 0 \\
$\mathrm{E}_{\text {DTT }}$ & 0 & 0,03 & 0
\end{tabular}

DT : Daerah Terkontrol

DTT : Daerah Tidak Terkontrol 
Pengaturan faktor eksposi yang digunakan adalah pada pemeriksaan CT-Scan Thorax dengan kontras yaitu menggunakan $120 \mathrm{kVp}$ dan $90 \mathrm{mAs}$. Skala dari surveymeter babyline yang digunakan adalah $10 \mu \mathrm{Gy} / \mathrm{jam}$ dan faktor kalibrasi 1,02. Pengukuran radiasi dilakukan disejoumlah titik pengukuran yang telah ditentukan.

Seanjutnya diperoleh laju paparan radiasi sebenarnya pada saat eksposi dilakukan, pada daerah terkontrol yaitu pada titik A didapatkan nilai laju paparan sebesar 4,86 $\mu \mathrm{Gy} / \mathrm{jam}$ dan pada titik $\mathrm{C}$ yang berada diruang operator diperoleh nilai laju paparan sebesar $0,04 \mu \mathrm{Gy} / \mathrm{jam}$. Seangkan pada daerah tidak terkontrol yaitu pada titik B yang berada di depan pintu pemeriksaan pasien diperoleh nilai laju paparan sebesar $3,36 \mu \mathrm{Gy} / \mathrm{jam}$, titik pengukuran D yang berada di ruang pemulihan diperoleh nilai laju paparan sebesar $0,06 \mu \mathrm{Gy} / \mathrm{jam}$, dan pada titik pengukuran E yang berada di ruang cuci tangan pasien nilai laju paparan sebesar $0,20 \mu \mathrm{Gy} / \mathrm{jam}$.

Keamanan Paparan Radiasi pada Ruang Pemeriksaan MSCT 64 Slice di Instalasi Radiologi RSUD Dr. Moewardi Surakarta.

Tabel 4.2 Hasil Pengukuran Laju Paparan Radiasi Sesungguhnya dan Laju Dosis Berdasarkan Ketinggian Suatu Tempat

\begin{tabular}{cccc}
\hline $\begin{array}{c}\text { Titik } \\
\text { Pengukuran }\end{array}$ & $\begin{array}{c}\text { Hasil pengukuran } \\
\text { sesungguhnya } \\
(\mu \mathrm{Gy} / \mathrm{jam})\end{array}$ & $\begin{array}{c}\text { Paparan yang } \\
\text { direkomen- } \\
\text { dasikan } \\
(\mu \mathrm{Sv} / \mathrm{jam})\end{array}$ & $\begin{array}{c}\text { Selisih } \\
\text { pengukuran } \\
(\mu \mathrm{Gy} / \mathrm{jam})\end{array}$ \\
\hline $\mathrm{A}_{\mathrm{DT}}$ & 4,86 & 0,03 & 4,83 \\
$\mathrm{C}_{\mathrm{DT}}$ & 0,02 & 0,03 & 0 \\
$\mathrm{~B}_{\mathrm{DTT}}$ & 3,16 & 0,03 & 3,13 \\
$\mathrm{D}_{\mathrm{DTT}}$ & 0 & 0,03 & 0 \\
$\mathrm{E}_{\mathrm{DTT}}$ & 0 & 0,03 & 0 \\
\hline $\mathrm{DT}$ & $\begin{array}{l}: \text { Daerah Terkontrol } \\
\text { DTT }\end{array}$ & Daerah Tidak Terkontrol & \\
\hline
\end{tabular}

Bedasarkan data diatas, diperoleh selisih pengukuran yaitu dengan mengurangkan hasil pengukuran sesungguhnya dengan batas paparan yang direkomendasikan menurut (UNSCEAR, 2000). Pada daerah terkontrol yaitu titik A yang berada dibelakang pintu operator diperoleh selisih pengukuran laju paparan sebsesar $4,83 \mu \mathrm{Gy} / \mathrm{jam}$ dan pada titik $\mathrm{C}$ yang berada di ruang operator diperoleh selisih pengukuran laju paparan sebesar $0 \mu \mathrm{Gy} / \mathrm{jam}$. Untuk daerah tidak terkontrol yaitu pada titik $\mathrm{B}$ yang berada di depan pintu pemeriksaan pasien diperoleh selisih pengukuran laju paparan sebesar $3,13 \mu \mathrm{Gy} / \mathrm{jam}$, sedangkan pada titik D yang berada di ruang pemulihan dan titik $\mathrm{E}$ yang berada di ruang cuci tangan pasien diperoleh selisih hasil pengukuran laju paparan sebesar $0 \mu \mathrm{Gy} / \mathrm{jam}$.
Untuk mengetahui berapa paparan yang terjadi pada titik-titik pengukuran, maka dibagi dengan faktor hunian (T). Faktor hunian menunjukkan lamanya seseorang berada di titik tersebut. Pengukuran laju paparan radiasi yang didapatkan dalam satuan $\mu \mathrm{Gy} / \mathrm{jam}$, sedangkan laporan NCRP No. 147 (2004) menggunakan satuan $\mathrm{mGy} / \mathrm{jam}$, maka untuk menyamakan satuan tersebut penulis mengkonversi satuan hasil ukur dari $\mu \mathrm{Gy} / \mathrm{jam}$ menjadi $\mathrm{mGy} / \mathrm{jam}$ dengan cara membagi dengan 10-3di bandingkan dengan Laju paparan yang di rekomendasikan dari NRCP No. 147 (2004)

Tabel 4.2 Hasil pembagian dengan faktor hunian (T) dan hasil konversi pengukuran laju papara radiasi dan Rekomendasi Laju Dosis Maksimum yang di perbolehkan menurut NCRP

\begin{tabular}{|c|c|c|c|c|c|c|}
\hline \multirow{2}{*}{$\begin{array}{l}\text { Titik } \\
\text { Penguku } \\
\text { ran }\end{array}$} & \multirow{2}{*}{$\begin{array}{c}\text { Jarak } \\
\text { Sumber } \\
\text { Radiasi } \\
\text { (m) }\end{array}$} & \multicolumn{2}{|c|}{$\begin{array}{c}\text { Hasil ukur laju paparan } \\
\text { radiasi sebenarnya } \\
(\mu \mathrm{Gv} / \mathrm{jam})\end{array}$} & \multirow{2}{*}{$\begin{array}{c}\text { Hasil } \\
\text { pengukuran } \\
\text { sesungguhny } \\
\text { a }(\mu \mathrm{Gg} / \mathrm{jam})\end{array}$} & \multirow{2}{*}{$\begin{array}{l}\text { Laju Paparan } \\
\text { yang di } \\
\text { Rekomendasika } \\
\mathrm{n}(\mu \mathrm{Gg} / \mathrm{jam})\end{array}$} & \multirow{2}{*}{$\begin{array}{c}\text { Selisih hasil } \\
\text { pengukuran } \\
(\mu \mathrm{Gx} / \mathrm{jam})\end{array}$} \\
\hline & & $\begin{array}{l}\text { Pada } \\
\text { Latar }\end{array}$ & $\begin{array}{c}\text { Pada } \\
\text { Saat eksposi }\end{array}$ & & & \\
\hline$\overline{A_{D T}}$ & 3 & 0,03 & 4,89 & 4,86 & 0,03 & 4,83 \\
\hline $\mathrm{C}_{\mathrm{DT}}$ & 3 & 0,02 & 0,04 & 0,02 & 0,03 & 0 \\
\hline $\mathrm{B}_{\mathrm{DTT}}$ & 4 & 0,20 & 3,36 & 3,16 & 0.03 & 3,13 \\
\hline $\mathrm{D}_{\mathrm{DTT}}$ & 2,5 & 0,06 & 0,06 & 0 & 0.03 & 0 \\
\hline $\mathrm{E}_{\mathrm{DTT}}$ & 5 & 0,20 & 0,20 & 0 & 0,03 & 0 \\
\hline & $\begin{array}{l}\text { DT } \\
\text { DTT }\end{array}$ & & $\begin{array}{l}\text { rah Terl } \\
\text { rah tida }\end{array}$ & $\begin{array}{l}\text { trol } \\
\text { erkontrol }\end{array}$ & & \\
\hline
\end{tabular}

Bedasarkan data diatas, menurut laporan NCRP No. 147 (2004) tentang desain struktur pelindung untuk fasilitas kesehatan. Menyebutkan bahwa laju dosis yang diperbolehkan untuk Daerah Terkontrol pada titik A dan titik $\mathrm{C}$ adalah sebesar $0,0025 \mathrm{mGy} / \mathrm{jam}$ sedangkan untuk Daerah tidak Terkontrol pada titik B, titik D dan titik E Laju Dosis yang di perbolehkan sebesar 0,005 mGy/jam.

Pada data diatas juga diperoleh hasil pembagian yang telah dikonversi menjadi $\mathrm{mGy} / \mathrm{jam}$. Pada daerah terkontrol yaitu titik A yang berada di belakang pintu operator menunjukkan hasil konversi pengukuran sebesar 0,03888 $\mathrm{mGy} / \mathrm{jam}$ dan titik $\mathrm{C}$ yang berada di ruang operator menunjukkan hasil konversi pengukuran sebesar 0,00002 mGy/jam. Pada titik B yang merupakan daerah tidak terkontrol menunjukkan hasil konversi pengukuran sebesar 0,02528 $\mathrm{mGy} / \mathrm{jam}$, sedangkan pada titik D dan E yang merupakan daerah tidak terkontrol menunjukkan hasil konversi pengukuran yang sama yaitu sebesar 0 $\mathrm{mGy} / \mathrm{jam}$

Observasi yang dilakukan penulis meliputi pengamatan langsung terhadap ukuran ruang pemeriksaan. Tujuannya untuk menentukan titik-titik dilakukannya pengukuran yang merujuk pada rekomendasi (UNSCEAR, 2000) dan untuk menentukan faktor hunian (T) yang mengacu pada publikasi laporan NCRP No. 147 (2004) 
tentang desain struktur pelindung untuk fasilitas kesehatan, dan observasi terhadap unit pesawat sinar-X.

a. Hasil Pengukuran Laju Paparan Radiasi Pada Ruang Pemeriksaan MSCT 64 Slice

Laju paparan radiasi pada Ruang Pemeriksaan MSCT 64 Slice di bedakan menjadi dua daerah, yakni Daerah Terkontrol dan Daerah tidak Terkontrol. Daerah Terkontrol meliputi titik di belakang pintu operator dan pada titik diruang operator, sementara Daerah tidak Terkontrol yaitu titik didepan pintu pemeriksaan pasien, titik di ruang pemulihan atau ruang tunggu pasien dan titik di ruang cuci tangan pasien.

Semua titik yang berada pada lokasi pengambilan data berada di ketinggian 93-95 m2 diatas permukaan laut. Menurut (UNSCEAR, 2000) paparan radiasi latar pada ketinggian tersebut termasuk salam kategori 0 meter diatas permukaan laut dan memiliki paparan radiasi sebesar $0,03 \mu \mathrm{Sv} / \mathrm{jam}$. Untuk membandingkan dengan ketentuan UNSCEAR, maka satuan dari hasil pengukuran radiasi latar perlu dikonversikan dari Gy menjadi Sv, karena radiasi yang digunakan adalah radiasi Sinar-X, dimana sinar-X memiliki faktor kualitas 1 maka diperoleh konversi sebagai berikut :

$$
\begin{aligned}
& 1 \mathrm{rad}=1 \mathrm{cGy} \\
& 1 \mathrm{rem}=1 \mathrm{cSv} \\
& 1 \mathrm{rad}=1 \mathrm{rem}=1 / 100 \mathrm{~J} / \mathrm{kg}
\end{aligned}
$$$$
1 / 100 \mathrm{~J} / \mathrm{kg}=1 \mathrm{cGy}=1 \mathrm{cSv} \ldots
$$

Perhitungan di atas menujukkan bahwa satuan Gy dengan Sv memiliki nilai sama. Sehingga hasil pengukuran radiasi latar tertinggi sebesar 0,03 $\mu \mathrm{Gy} / \mathrm{jam}$ sama dengan $0,03 \mu \mathrm{Sv} / \mathrm{jam}$, dengan demikian nilai laju paparan pada beberapa titik pengukuran bisa dibandingkan dengan ketentuan UNSCEAR.

Paparan radiasi latar (background) menunjukkan paparan alami dimana tidak terjadi tambahan paparan radiasi lainnya, maka jika terdapat nilai paparan yang melebihi nilai paparan radiasi latar maka dapat disimpulkan jika terdapat radiasi tambahan pada lokasi tertentu.Terkait dengan lokasi penelitian pada titik yang berada di belakang pintu operator terdapat shielding barier berupa Tabir $\mathrm{Pb} 2 \mathrm{~mm}$ diperoleh hasil

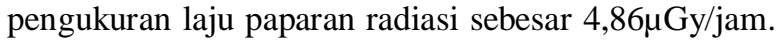
Sedangkan pada titik di depan pintu pemeriksaan pasien diperoleh hasil pengukuran laju paparan radiasi sebesar 3,16 $\mu \mathrm{Gy} / \mathrm{jam}$.

Hasil pengukuran pada kedua titik tersebut melampaui batas radiasi latar (background) yang diperbolehkan menurut (UNSCEAR, 2000), hal ini menunjukkan adanya nilai paparan tambahan di luar radiasi latar. Sehingga dapat disimpulkan pada titik dibelakang pintu operator dan titik di depan pintu pemeriksaan pasien terjadi kebocoran paparan radiasi.
Faktor penyebab kebocoran yang terjadi pada titik di belakang pintu operator dimungkinkan terjadi karena bagian dari pintu tersebut tidak mengikuti rekomendasi standar pelindung radiasi yang baku. Pada bagian pintu tidak terdapat lapisan Pb. Pintu terbuat dari bahan yang masih bisa ditembus radiasi yakni bahan galvalum. Setelah dipasang Perisai $\mathrm{Pb}$ sebagai penahan radiasi yang mengarah ke pintu namun masih terdapat kebocoran radias. Hall tersebut di mungkinkan karena masih terdapat celah di bawah tabir, dan posisi tabir yang kurang tepat sehingga tidak evektif dalam menahan radiasi yang mengarah ke pintu operator.

Sedangkan faktor kebocoran kebocoran yang terjadi di pintu pemeriksaan pasien dimungkinkan karena terdapat celah yang berada di tengah pintu tepatnya dibagian bawah, meskipun pengukuran dilakukan $1 \mathrm{~m}$ diatas permukaan tanah namun hamburan radiasi masih mencapai alat ukur surveymeter.

Selanjutnya pada titik yang berada di ruang operator diperoleh hasil pengukuran laju paparan radiasi sebesar $0,2 \mu \mathrm{Gy} / \mathrm{jam}$, pada titik di ruang pemulihan pasien dan pada titik di ruang cuci tangan pasien diperoleh hasil pengukuran laju paparan radiasi dengan nilai yang sama yaitu $0 \mu \mathrm{Gy} / \mathrm{jam}$.

Hasil pengukuran pada ketiga titik tersebut tidak melampaui batas radiasi latar (background) yang diperbolehkan menurut (UNSCEAR, 2000). Sehingga dapat disimpulkan pada titik di ruang operator, ruang pemulihan pasien dan ruang cuci tangan pasien tidak terjadi kebocoran paparan radiasi.

b. Keamanan Paparan Radiasi Pada Ruang Pemeriksaan MSCT 64 Slice

Untuk mengetahui keamanan paparan radiasi pada ruang pemeriksaan MSCT 64 Slice yaitu dengan mengetahui berapa paparan yang terjadi pada titik-titik pengukuran. Selanjutnya titik-titik pengukuran dibagi dengan faktor hunian (T) dan di konversi menjadi mGy/jam. Kemudian dibandingkan dengan laporan NRCP No. 147 (2004) tentang desain struktur pelindung untuk fasilitas kesehatan.

Menurut laporan NRCP No. 147 (2004), untuk Daerah Terkontrol nilai laju paparan radiasi yang diperbolehkan dalam batas 0,0025 mGy/jam, sedangkan untuk Daerah tidak Terkontrol nilai laju paparan radiasi yang diperbolehkan dalam batas $0,0005 \mathrm{mGy} / \mathrm{jam}$. Sehingga jika didapat nilai paparan radiasi yang melampaui dari batas tersebut maka dapat disimpulkan pada titik tersebut tidak aman bagi petugas dan masyarakat.

Pada titik yang berada dibelakang pintu ruang operator termasuk daerah terkontrol dimana diperoleh hasil pengukuran sebesar $0,0388 \mathrm{mGy} / \mathrm{jam}$. Sedangkan pada titik di depan pintu pemeriksaan pasien termasuk 
Daerah tidak Terkontrol dimana diperoleh hasil pengukuran paparan sebesar 0,0252. $\mathrm{mGy} / \mathrm{jam}$.

Pada kedua titik tersebut diperoleh nilai laju paparan yang melebihi standar aman menurut NRCP No. 147 (2004). Maka dapat disimpulkan dari hasil pengukuran titik dibalik pintu operator dan titik didepan pintu pemeriksaan, nilai paparan radiasi tidak aman bagi petugas dan masyarakat.

Sedangkan pada titik di ruang operator yang merupakan Daerah Terkontrol dimana diperoleh hasil pengukuran paparan sebesar 0,0002 mGy/jam. Selanjutnya pada titik yang berada diruang pemulihan pasien dan titik di ruang cuci tangan yang merupakan Daerah tidak Terkontrol diperoleh hasil pengukuran sebesar $0 \mathrm{mGy} / \mathrm{jam}$.

Pada ketiga titik tersebut diperoleh nilai laju paparan yang masih dalam batas standar aman menurut NRCP No. 147 (2004). Maka dapat disimpulkan dari hasil pengukuran titik di ruang operator, ruang pemulihan pasien, dan ruang cuci tangan pasien nilai paparan radiasi masih dalam batas aman bagi petugas dan masyarakat.

\section{Simpulan}

Hasil pengukuran laju paparan radiasi pada titik A yang berada di belakang pintu operator dan titik B yang berada di depan pintu pemeriksaan menunjukkan nilai laju paparan radiasi yang melebihi nilai paparan latarnya, hal ini berarti bahwa masih terjadi kebocoran pada titik tersebut. Kebocoran radiasi tertinggi terjadi pada titik A. Sedangkan pada titik $\mathrm{C}$ berada di ruang operator, titik D yang berada di ruang pemulihan pasien dan titik $\mathrm{E}$ berada di ruang cuci tangan menunjukkan nilai laju paparan radiasi yang tidak melebihi paparan latar tidak terdapat kebocoran paparan radiasi. Nilai laju paparan latar (background) di ruang pemeriksaan MSCT 64 Slice melebihi laju dosis berdasarkan ketinggian lokasi menurut UNSCEAR Berdasarkan hasil pengukuran di ruang pemeriksaan MSCT 64 Slice pada titik A yaitu di balik pintu operator dan titik B yang berada di depan pintu pemeriksaan pasien tidak aman bagi petugas dan masyarakat karena melebihi batas toleransi paparan yang diperbolehkan. Sedangkan pada titik b, titik d, dan titik c aman bagi petugas dan masyarakat karena tidak melebihi batas toleransi paparan yang diperbolehkan.

\section{Saran}

Sarannya adalah Sebaiknya dilakukan perbaikan pada pintu ruang pemeriksaan pasien, sehingga tidak ada celah yang mengakibatkan kebocoran paparan radiasi. Sebaiknya dilakukan penggantian pintu operator sesuai standar kelayakan fasilitas kesehatan, yaitu pintu dilapisi $\mathrm{Pb}$ dengan ketebalan $2 \mathrm{~mm}$.

\section{Daftar Pustaka}

Akhadi, Mukhlis. 2000. Dasar - Dasar Proteksi Radiasi. PT. Rineka Cipta. Jakarta.

Batan. 2005. Pengenalan Radiasi. Pusdiklat Batan. www.batan.go.id diakses pada 20 Januari 2018 pukul 18.00 .

Batan. 2009. Prinsip Dasar Pengukuran Radiasi. Pusdiklat Batan. www.batan.go.id diakses pada 19 Januari 2018 pukul 14.30.

Bapeten. 2011. Peraturan Kepala Badan Tenaga Nuklir Nomor 8 Tahun 2011 tentang Keselamatan Radiasi Dalam Penggunaan Pesawat sinar-X Radiologi Diagnostik dan Intervensional. Jakarta: Bapeten.

Bapeten. 2013. Peraturan kepala Badan Pengawas Tenaga Nuklir Nomor 4 Tahun 2013 tentang Proteksi dan Keselamatan Tenaga Nuklir. Jakarta: Bapeten.

National Council on Radiation Protection an Measurements. 2004. Report No. 147- structural shielding Design for Medical X-ray Imaging Facilities. Bethesda: NCRP.

IAEA. Radiation Protection In Diagnostic And Interventional Radiology http://www.rpop.iaea.org/rpop/rpop/content/Docu ment/TrainingRadiology/lectures/rpdir112_shielding.web Diakses pada 23 Januari 2018 pukul.10.58.

Rasad, Sjahrir. 2009. Radiologi Diagnostik Edisi Kedua. Jakarta: Balai Penerbit FK UI.

Sherer, MAS, Visconti, PJ \& Ritenour, ER. 2006. Radiation Protection In Medical Radiography. Canada: Mosby. Inc.

United Nations Scientific Committe of the Effects of Atomic Radiation. 2008. Sources,Effects and Risks of Ionizing Radiation. Volume I. United Nations Scientific Committe on the Effects of Atomic Radiation. New York (S): UNSCEAR. 